\title{
Antibacterial compounds from Rutaceae with activities against Flavobacterium columnare and Streptococcus iniae
}

\author{
Kumudini M. Meepagala ${ }^{1^{*}}$, Kevin K. Schrader ${ }^{2}$, Charles L. Burandt ${ }^{2}$ \\ ${ }^{1}$ USDA-ARS, Natural Products Utilization Research Unit, University, MS, USA; \\ *Corresponding Author: kmeepaga@olemiss.edu \\ ${ }^{2}$ University of Mississippi National Center for Natural Products Research, University, MS, USA
}

Received 25 July 2013; revised 7 September 2013; accepted 19 September 2013

Copyright (c) 2013 Kumudini M. Meepagala et al. This is an open access article distributed under the Creative Commons Attribution License, which permits unrestricted use, distribution, and reproduction in any medium, provided the original work is properly cited.

\begin{abstract}
From the ethyl acetate extract of Murraya koenegii (Rutaceae) leaves, isomahanine (1) and mahanine (2) were isolated that showed antibacterial activity towards Flavobacterium columnare and Streptococcus iniae which caused columnaris disease and streptococcosis respectively. Isomahanine was found to have the strongest activity against $F$. columnare (isolate ALM-00-173) and $S$. iniae (isolate LA94-426) based on $24-\mathrm{h} 50 \%$ inhibition concentration $\left(\mathrm{IC}_{50}\right)$ and minimum inhibition concentration (MIC). Although compound (7), a nicotinamide isolated from Amyris texana had the lowest MIC (2.8 \pm 0 $\mathrm{mg} / \mathrm{L}$ ) of any of the test compounds against $F$. columnare, the $24-\mathrm{h} \mathrm{IC}_{50}$ of $14.8 \pm 0.6 \mathrm{mg} / \mathrm{L}$ was higher than that of isomahanine and subsequently the 24-h IC ${ }_{50}$ RDC values for (7) were almost a magnitude of order higher than those obtained for isomahanine. Isomahanine also had the strongest activity against $S$. iniae, with a 24-h IC $\mathrm{I}_{50}$ of $1.3 \pm 0.1 \mathrm{mg} / \mathrm{L}$ and MIC of $3.5 \pm 0$ $\mathrm{mg} / \mathrm{L}$, respectively.
\end{abstract}

Keywords: Murraya koenigii; Amyris texana; Piper nigrum; Columnaris Disease; Flavobacterium columnare; Streptococcosis; Streptococcus iniae; Aquaculture

\section{INTRODUCTION}

Pond-raised channel catfish (Ictalurus punctatus) is the largest segment of aquaculture in the United States. Columnaris disease is one of the most common bacterial diseases of pond-raised channel catfish in the southeast- ern US [1]. Mortalities in pond populations of catfish from columnaris disease can be as high as 50\% - 60\% [1]. Direct economic losses to catfish producers are likely millions of dollars annually from single or mixed infections involving $F$. columnare [2]. The Gram-negative, rod-shaped bacterium Flavobacterium columnare is the cause of columnaris disease. Two genomovars of $\mathrm{F}$. columnare have been identified, with genomovar II isolates attributed as being more pathogenic towards channel catfish [3]. The US Food and Drug Administration (FDA) has granted conditional approval of Aquaflor ${ }^{\circledR}$ (50\% florfenicol active ingredient) for treating columnaris disease in channel catfish [4].

Streptococcosis is a common bacterial disease of tilapia species and can also cause disease in many other freshwater fish species including hybrid striped bass [Morone chrysops female $\times$ Morone saxatilis male (Percichthyidae)] and to a lesser extent in pond-cultured channel catfish [5]. Although there are several species of bacteria associated with the cause of streptococcosis in freshwater fish, the most common species responsible for streptococcosis in tilapia is Streptococcus iniae which is a Gram-positive spherical-shaped cell. Streptococcosis is a major disease in cultured tilapia (Oreochromis spp.) in North America and is likely a limiting factor in expansion of this segment of aquaculture due to very high mortality rates (e.g., up to $75 \%$ in cultured tilapia) [1].

There are several management approaches for columnaris disease currently available to producers including the application of medicated feeds, attenuated vaccines [6], and nonantibiotic therapeutants such as 35\% PeroxAid $^{\circledR}$ for external columnaris [1]. However, Perox-Aid ${ }^{\circledR}$ is not recommended for use in earthen ponds unless water exchange is implemented. The efficacy of other potential therapeutants such as copper sulfate pentahydrate $\left(\mathrm{CuSO}_{4} \cdot 5 \mathrm{H}_{2} \mathrm{O}\right)$ and potassium permanganate $\left(\mathrm{KMnO}_{4}\right)$ 
can be adversely impacted by certain water quality variables. Therefore, producers must use extra care when utilizing these therapeutants due to their broad-spectrum toxicity towards non-target organisms such as channel catfish and beneficial algae [7].

The preventive management practices for streptococcosis include maintaining high water quality, application of high-quality diets, adequate water exchange and disinfection, and removal of fecal waste from recirculating water systems [1]. Although no chemotherapeutants are currently approved for treating streptococcosis in cultured fish in the US, vaccination appears to be a promising approach for protection against $S$. iniae infection in Nile tilapia [5].

The discovery of environmentally safe, cost effective antibacterial compounds would benefit aquaculturists due to the limitations or the absence of current management approaches available for controlling the common bacterial species responsible for columnaris disease and streptococcosis. Many members in the Rutaceae family are sources of diverse classes of natural products with biological activities including antifungal, phytotoxic, and antidotal activities [8-14]. For the current study, a rapid bioassay was used to evaluate compounds isolated from ethyl acetate extract of Murraya koenigii (Linn.) Spreng. (Rutaceae) leaves, several amides isolated from Amyris texana P. Wilson (Rutaceae) and some synthetic analogs of the amides in Piper nigrum (Piperaceae) for antibacterial activity against $F$. columnare and $S$. iniae.

\section{MATERIALS AND METHODS}

\subsection{Plant Material}

M. koenigii leaves (grown and collected in Hawaii) and $P$. nigrum seeds were purchased from local grocery stores. Leaves of A. texana were collected in Cameron Co. in South Texas, during June, 2002. A voucher specimen (BUR 190204 a) was deposited at the University of Mississippi herbarium. The leaves of both specimens were air-dried, ground, and stored at room temperature until they were extracted.

\subsection{Extraction}

Air-dried M. koenigii leaves $(1.0 \mathrm{~kg})$ were homogenized with ethyl acetate ( $2 \mathrm{~L}$ ) in a commercial blender at ambient temperature and extracted twice for $12 \mathrm{~h}$ with ethyl acetate (4 L). Following filtration through filter paper (Whatman \#1), the combined ethyl acetate extract was concentrated under reduced pressure at $40^{\circ} \mathrm{C}$ to afford $27.5 \mathrm{~g}$ of green oily mass. $A$. texana leaves were extracted and fractionated as described previously [9]. $P$. nigrum seeds were extracted by crushing the fruits (500 g) in a commercial blender at ambient temperature with $\mathrm{CH}_{2} \mathrm{Cl}_{2}(1 \mathrm{~L} \times 3)$. The extracts were filtered through fil- ter paper (Whatman \#1) and the solvent was evaporated to yield a greenish-brown extract (26.7 g).

\subsection{General Chemical Methods}

Extracts were analyzed on 250-micron silica gel TLC plates GF with fluorescent indicator (Analtech, Newark, DE, USA). Iodine vapor, UV light (at $254 \mathrm{~nm}$ and 365 $\mathrm{nm}$ ), and Dragendorff's and anisaldehyde spray reagents were used for the detection of compounds. Column chromatography was carried out by a Biotage flash chromatography system. All solvents were reagent grade and used without further purification. ${ }^{1} \mathrm{H}$ and ${ }^{13} \mathrm{C}$ NMR spectra were recorded on a Varian Mercury AS400 spectrometer operating at $400 \mathrm{MHz}$ for ${ }^{1} \mathrm{H}$ NMR and at 100 $\mathrm{MHz}$ for ${ }^{13} \mathrm{C}$ NMR. The HR-ESIMS was measured by using a Jeol ACCU TOF JMS-T1000 mass spectrometer.

\subsection{Antibacterial Bioassay}

An isolate of Flavobacterium columnare [isolate ALM-00-173 (genomovar II)] was obtained from Dr. Covadonga Arias (Department of Fisheries and Allied Aquacultures, Auburn University, Auburn, Alabama). Cultures of the $F$. columnare isolate were maintained separately on modified Shieh (MS) agar plates (pH 7.2 7.4) in order to assure purity (15]. Prior to conducting the bioassay, single colonies of $F$. columnare were used to prepare the assay culture material by culturing in $75 \mathrm{~mL}$ of MS broth $(24 \mathrm{~h})$ at $29^{\circ} \mathrm{C} \pm 1^{\circ} \mathrm{C}$ at $150 \mathrm{rpm}$ on a rotary shaker (model C24KC; New Brunswick Scientific, Edison, New Jersey). After overnight incubation, a 0.5 McFarland standard of $F$. columnare assay material was prepared by transferring cells from the broth culture to fresh MS broth [2]. A culture of $S$. iniae (isolate LA94426) was provided by Dr. Ahmed Darwish (formerly at U.S. Department of Agriculture, Agricultural Research Service, Harry K. Dupree Stuttgart National Aquaculture Research Center, Stuttgart, Arkansas). In order to assure purity, cultures of $S$. iniae were maintained on plates of Columbia CNA agar containing 5\% sheep blood (Remel, Inc., Lenexa, Kansas). Bioassay culture material of $S$. iniae was prepared in the same manner and conditions as those used for the $F$. columnare isolate, except 3.8\% $\mathrm{MH}$ broth was used and the broth cultures were incubated for $18 \mathrm{~h}$ instead of $24 \mathrm{~h}$ prior to preparing a bacterial cell suspension of 0.5 MacFarland standard.

Pure compounds were evaluated for antibacterial activity using a rapid 96-well microplate bioassay and following the procedures of Schrader and Harries [2]. Florfenicol and oxytetracycline $\mathrm{HCl}$, antibiotics that can be utilized in medicated feed, were included as positive drug controls. In addition, control wells (no test compound) were included in each assay. All pure test compounds were dissolved separately in technical grade 
methanol. Drug controls were dissolved in technical grade ethanol. Final concentrations of test compounds and drug controls were $0.01,0.1,1.0,10.0$, and 100.0 $\mu \mathrm{M}$. Three replications were used for each dilution of each test compound and controls. Final results were converted to units of $\mathrm{mg} / \mathrm{L}$ to allow comparison with previous studies.

In order to determine the 24 -h $50 \%$ inhibition concentration $\left(\mathrm{IC}_{50}\right)$ and minimum inhibition concentration (MIC), sterile 96-well polystyrene microplates (Corning Costar Corp., Acton, Massachusetts) with flat-bottom wells were used. Initially, dissolved test compound or drug controls were micropippeted separately into individual microplate wells $(10 \mu \mathrm{L} /$ well $)$, and solvent was allowed to completely evaporate before 0.5 MacFarland bacterial culture [prepared as described by Schrader and Harries [2]] was added to the microplate wells (200 $\mu \mathrm{L} /$ well). Microplates were incubated at $29 \pm 1^{\circ} \mathrm{C}$ (VWR model 2005 incubator; Sheldon Manufacturing, Inc., Cornelius, Oregon). A Packard model SpectraCount microplate photometer (Packard Instrument Company, Meriden, Connecticut) was used to measure the absorbance $(630 \mathrm{~nm})$ of the microplate wells at time 0 and $24 \mathrm{~h}$.

The means and standard deviations of absorbance measurements were calculated, graphed, and compared to controls to help determine the 24-h $\mathrm{IC}_{50}$ and MIC for each test compound [2]. The 24-h $\mathrm{IC}_{50}$ and MIC results for each test were divided by the respective 24-h $\mathrm{IC}_{50}$ and MIC results (in $\mu \mathrm{M}$ ) obtained for the positive controls florfenicol and oxytetracycline to determine the relativeto-drug-control florfenicol (RDCF) and relative-to-drugcontrol oxytetracycline (RDCO) values.

\subsection{Isolation of Isomahanine (1) and Mahanine (2)}

Ethyl acetate extract of M. koenigii leaves (25 g) was applied to a Biotage silica gel column (65i) and fractionated with ethyl acetate in hexane $(0 \%-50 \%)$, and fractions with similar TLC profiles were combimed to obtain 12 fractions. Fraction 8 was rid of chlorophyll by passing through a short florosil column $(10 \mathrm{~cm}, 2 \mathrm{~cm}$ id) eluting with hexane followed by $50 \% \mathrm{CH}_{2} \mathrm{Cl}_{2}$ in hexane. The chlorophyll-free fraction was further purified with column chromatography using a Biotage silica gel column (12 M) using $10 \%$ ethyl acetate in $\mathrm{CH}_{2} \mathrm{Cl}_{2}$. Isomahanine (1) and mahanine (2) were eluted as pure compounds and were crystallized as white crystals using $\mathrm{CH}_{2} \mathrm{Cl}_{2}$ and hexane. HPLC analysis was carried out under isocratic condition with 5:95 EtOAc:CH2Cl2, using a Phenomenex Luna ${ }^{\circledR} 5 \mu \mathrm{m}$ Silica (2) $100 \AA$, LC Column $250 \times 4.6$ $\mathrm{mm}$, at Flow rate: $1 \mathrm{~mL} / \mathrm{min}$. The identity was confirmed by comparison of ${ }^{1} \mathrm{H}$ and ${ }^{13} \mathrm{C}$ NMR data with those reported in the literature $[16,17]$.

\subsection{Isolation of Piperine (3)}

The $\mathrm{CH}_{2} \mathrm{Cl}_{2}$ extract of P. nigrum (25 g) was dissolved in $200 \mathrm{~mL} \mathrm{CH}_{2} \mathrm{Cl}_{2}$, and hexane $(150 \mathrm{~mL})$ was added to obtain pale yellow crystals which were filtered and recrystallized with $\mathrm{CH}_{2} \mathrm{Cl}_{2}$ and hexane to obtain off-white needle-like crystals $(6.4 \mathrm{~g})$. These crystals were identified as piperine (1), the major constituent in the extract, by $1 \mathrm{H}$ NMR spectroscopic data [18]. The remaining extract (16 g) was adsorbed onto a silica gel column and eluted with hexane and increasing amounts of $\mathrm{CH}_{2} \mathrm{Cl}_{2}$.

\subsection{Isolation of Pellitorine (4)}

Purification of fraction 12 by PTLC afforded a compound which showed a positive reaction with Dragendorff's reagent and was crystallized by hexane and $\mathrm{CH}_{2} \mathrm{Cl}_{2}$ to afford white crystals (39 mg). The identity of (4) was established by ${ }^{1} \mathrm{H}$ NMR mass spectroscopic data and synthesis.

\subsection{Isolation of (5), (6), (7)}

Ethyl acetate extract of $A$. texana leaves (20.0 g) was subjected to column chromatography on silica gel, eluting with hexane and then with increasing amounts of acetone (up to 100\%), and fractionated as described previously [Meepagala et al., 2010). Fractions of $400 \mathrm{~mL}$ were collected and the elution profile of the column was monitored by TLC. The fractions with similar TLC profiles were combined to yield 34 fractions. Fraction 24 was further purified by crystallization with ethyl acetate in hexane to obtain (5) (480 mg) as yellow crystals. The identity was confirmed by comparison of NMR data with those published in the literature [19]. Fraction 27 (1.1 g) was further purified by silica gel chromatography using $10 \%-30 \%$ acetone in hexane followed by crystallization with ethyl acetate in hexane to obtain (6) $(157 \mathrm{mg})$ as white crystals and (7) (380 mg) as yellow crystals. The identity (7) was confirmed by comparison of spectroscopic data with those published in the literature [20). Compound (6) HRESI-MS: 412.24840 (calc. for $\left.\mathrm{C}_{25} \mathrm{H}_{34} \mathrm{NO}_{4}, 412.24878\right),{ }^{1} \mathrm{H}$ NMR $\delta\left(\mathrm{CDCl}_{3}\right) 1.156(6 \mathrm{H}$, d, $J=14.4 \mathrm{~Hz}, \mathrm{Ha}, \mathrm{Hb}), 1.48$ - $1.42(1 \mathrm{H}, \mathrm{m}, \mathrm{Hd} / \mathrm{e}), 1.64$ $1.57(1 \mathrm{H}, \mathrm{m}, \mathrm{Hd} / \mathrm{e}), 1.722$ (3H, s, Hc), 2.15-2.08 $(1 \mathrm{H}, \mathrm{m}$, $\mathrm{Hg} / \mathrm{f}), 2.36-2.30(1 \mathrm{H}, \mathrm{m}, \mathrm{Hg} / \mathrm{f}), 2.84(2 \mathrm{H}, \mathrm{t}, J=6.4 \mathrm{~Hz}$, Hh), $3.30(1 \mathrm{H}, \mathrm{d}, J=10 \mathrm{~Hz}, \mathrm{Hj}) 3.63(2 \mathrm{H}, \mathrm{td}, J=10.8$ $\mathrm{Hz}$ and $6 \mathrm{~Hz}, \mathrm{Hi}), 4.50(2 \mathrm{H}, \mathrm{d}, J=6.4 \mathrm{~Hz}, \mathrm{Hk}), 5.51(1 \mathrm{H}$, $\mathrm{t}, J=5.6, \mathrm{Hl}), 6.46(1 \mathrm{H}, \mathrm{t}, J=5.6, \mathrm{Hm}), 6.84(2 \mathrm{H}, \mathrm{d}, J=$ $8.4 \mathrm{~Hz}, \mathrm{Hn}), 7.10(2 \mathrm{H}, \mathrm{d}, J=8.4 \mathrm{~Hz}, \mathrm{Ho}), 7.37$ (2H, t, $J$ $=4 \mathrm{~Hz}, \mathrm{Hp}), 7.43(1 \mathrm{H}, \mathrm{t}, J=8 \mathrm{~Hz}, \mathrm{Hq}), 7.68(2 \mathrm{H}, \mathrm{d}, J=$ $7.6 \mathrm{~Hz}),{ }^{13} \mathrm{C}$ NMR $\delta 16.7$ (c), $23.2(\mathrm{a}), 26.4$ (b), 29.5 (d,e), 34.8 (h), 36.6 (f,g), 41.5 (i), 64.8 (k), 73.0 (u), 78 (j), 114.9 (n) 119.85 (l), 126.9 (r), 128.5 (p), 129.7 (o), 130.9 (w), 131.5 (q), 134.5 (x), 141.2 (s), 157.5 (v), 167.8 
( $\mathrm{C}=\mathrm{O}$ carbonyl).

The NMR data for (6) has not been reported unambiguously even though several analogs of (6) have been reported [21,22].

\subsection{Piperic Acid (8)}

Piperine ( $4.0 \mathrm{~g}$ ) was refluxed with excess $10 \% \mathrm{NaOH}$ in methanol for $12 \mathrm{~h}$ and then the methanol was evaporated, the reaction mixture was acidified with $2 \mathrm{~N} \mathrm{HCl}$, and the mixture extracted with ethyl acetate. The ethyl acetate layer was dried with anhydrous $\mathrm{Na}_{2} \mathrm{SO}_{4}$ and evaporated to obtain yellow solid, crystallized as yellow needles with ethyl acetate in hexane $(3.1 \mathrm{~g}, 98 \%)$. The identity was confirmed by NMR and GC-MS.

\subsection{Synthesis of 9}

A mixture of 8 (0.218g, $0.1 \mathrm{mmol})$ and BBDI (0.15 mmol) in $\mathrm{CH}_{2} \mathrm{Cl}_{2}(20 \mathrm{~mL})$ was stirred at room temperature for $30 \mathrm{~min}$. After addition of pyrrolidine $(0.2 \mathrm{mmol})$, the reaction mixture was stirred at reflux for $6 \mathrm{~h}$. Ethyl acetate $(30 \mathrm{~mL})$ was added to the reaction mixture and then the reaction mixture was washed with $1 \mathrm{M} \mathrm{HCl}$ solution $(25 \mathrm{~mL} \times 2), 10 \% \mathrm{Na}_{2} \mathrm{CO}_{3}(25 \mathrm{~mL} \times 2)$, and saturated $\mathrm{NaCl}\left(20 \mathrm{~mL}\right.$ ), dried over (anhy. $\mathrm{Na}_{2} \mathrm{SO}_{4}$ ), and concentrated under reduced pressure to afford a brownish residue which was purified by Biotage silica gel flash column chromatography to give 9 using 5\% - 50\% ethylacetate in hexane as pale yellow neeedles. Identity was confirmed as $E, E$-piperinoylpyrrolidine (9) by comparison of NMR data [23].

\subsection{Synthesis of 10 and 13}

A solution of 6-bromohexanoate (66 g, 0.3 moles) and triphehylphosphine (78.6 g, 0.3 moles) in toluene $(1.0 \mathrm{~L}$ ) was refluxed for $48 \mathrm{~h}$ under $\mathrm{N}_{2}$. Toluene was evaporated to obtain a viscous sticky solid and this was washed with hexane to afford ethoxycarbonylpentyl-triphenyl-phosphonium bromide (118.6 g, $24.4 \mathrm{mmol}$ ). The identity was confirmed by comparison of NMR data with those published [24]. This was refluxed with piperonal (36.6 g, 24 mmol) and $\mathrm{Cs}_{2} \mathrm{CO}_{3}$ (79.6 g, $24.4 \mathrm{mmol}$ ) for $24 \mathrm{~h}$ under $\mathrm{N}_{2}$, in toluene $(750 \mathrm{~mL})$. The reaction mixture was cooled, supernatant was decanted, the solid was washed with hexane, the hexane wash was combined with the supernatant, and the solvent was evaporated to obtain a pale yellow oil. The product was purified by silica gel Biotage flash column chromatography using $0 \%-10 \%$ ethylacetate in hexane to afford $\mathbf{1 0}$ as a pale yellow oil (82 $\mathrm{g}$ ). GC-MS and NMR indicated that $\mathbf{1 0}$ was a mixture of $c i s$ and trans isomers in 10:7 (cis:trans) ratio. The identity was confirmed by comparison of NMR data published in literature [25].

Cis and Trans Isomer Mixture of (10) (6.9 g, 0.025 mol) and palladium on charcoal ( $0.5 \mathrm{~g}, 10 \%)$ in $75 \mathrm{~mL}$ of absolute ethanol were hydrogenated on a Parr Shaker for $12 \mathrm{~h}$ at $37 \mathrm{psi}$. After filtration through Celite, the filtrate was concentrated in vacuo to give $6.4 \mathrm{~g}$ (92\% yield) of (13) as a light yellow oil; NMR (CDCl3) $\delta 1.25(\mathrm{t}, 3 \mathrm{H}, \mathrm{J}$ $=8 \mathrm{~Hz}), 1.33(\mathrm{~m}, 4 \mathrm{H}), 1.59(\mathrm{~m}, 4 \mathrm{H}), 2.28(\mathrm{t}, 2 \mathrm{H}, \mathrm{J}=8$ $\mathrm{Hz}$ ), 2.51 (t, 3H, J = $8 \mathrm{~Hz}$ ), 4.11 (q, 2H, J = $8 \mathrm{~Hz}) .5 .9$ (s, $2 \mathrm{H}), 6.60(1 \mathrm{H}, \mathrm{d}, \mathrm{J}=8 \mathrm{~Hz}), 6.66(1 \mathrm{H}, \mathrm{s}) .6 .71(\mathrm{~d}, 1 \mathrm{H}, \mathrm{J}=$ $8 \mathrm{~Hz}$ ); HRESI-MS $\left(\mathrm{M}^{+}\right) 272.15182$ (calc. for $\mathrm{C}_{16} \mathrm{H}_{22} \mathrm{O}_{4}$, 278.15181).

\subsection{Synthesis of 11}

A solution of $\mathbf{1 0}$ (12 g, 0.043 moles) in anhydrous ether $(50 \mathrm{~mL})$ was added dropwise to an ice-cold stirred slurry of $\mathrm{LiAlH}_{4}$ (0.8 g, 0.021 moles) in anhydrous ether $(100 \mathrm{~mL})$ and allowed to come to room temperature and let stand for $2 \mathrm{~h}$. Excess $\mathrm{LiAlH}_{4}$ was destroyed by addition of ethyl acetate and then $0.5 \mathrm{M} \mathrm{NaOH}$. The solution was decanted and partitioned between water and ethyl acetate, and the organic layer was dried with anhydrous $\mathrm{Na}_{2} \mathrm{SO}_{4}$ and the solvent was evaporated and purified with silica gel Biotage flash column chromatography using $5 \%-30 \%$ ethyl acetate in hexane to afford $\mathbf{1 1}$ as a viscous oil. The identity was confirmed by comparison of NMR data with those published in the literature [26].

\subsection{Synthesis of 12 and 4}

Compound 12 was synthesized by oxidation of (2E,4E) deca-2,4-dienal (1.4 g) via treatment with $40 \% \mathrm{Ag}\left(\mathrm{NO}_{3}\right)$ (20 mL) in $\mathrm{NaOH}\left(10 \%\right.$ in $\left.\mathrm{H}_{2} \mathrm{O}\right)$ at room temperature for $6 \mathrm{~h}$ followed by acidification with $1 \mathrm{~N}$ HCL and extraction with ethyl acetate. Purification was done by Biotage flash column chromatography using $20 \%$ - 90\% ethyl acetate in hexane to obtain $\mathbf{1 2}$ as pale white crystals (820 $\mathrm{mg})$. Compound 12 in benzene $(6 \mathrm{~mL})$ was treated with excess oxalyl chloride (4 mL) and refluxed for $10 \mathrm{~min}$ to obtain the corresponding acid chloride. Excess reagent and benzene were evaporated, dissolved in $\mathrm{CH}_{2} \mathrm{Cl}_{2}$ (20 $\mathrm{mL}$ ), cooled in an ice bath, treated with excess isobutyl amine (7 mL) under $\mathrm{N}_{2}$, and allowed to stand for $15 \mathrm{~min}$. Solvent was evaporated, cooled on ice, acidified with 1 $\mathrm{N} \mathrm{HCl}$, extracted with ethyl acetate, and purified by silica gel flash column chromatography using 10\% - 70\% ethyl acetate in hexane to afford $\mathbf{4}$ as white needles after crystallization. The identity was confirmed by comparison of NMR data with those published in the literature [27].

\section{RESULTS AND DISCUSSION}

From the initial antibacterial bioassay, the ethyl acetate extract of leaves of $M$. koenigii showed moderate activity against $F$. columnare and $S$. iniae. The $24-\mathrm{h} \mathrm{IC}_{50}$ was $17 \mathrm{mg} / \mathrm{L}$ while the MIC was $0.1 \mathrm{mg} / \mathrm{L}$ against $S$. 
iniae LA94-426. Among the compounds evaluated, isomahanine isolated from $M$. koenigii was found to have the strongest activity against $F$. columnare based on 24-h $\mathrm{IC}_{50}$ and MIC of $1.9 \pm 0.2 \mathrm{mg} / \mathrm{L}$ and $3.5 \pm 0 \mathrm{mg} / \mathrm{L}$, respectively (Table 1). The relative-to-drug-control (RDC) values for isomahanine were also among the lowest, especially the 24-h $\mathrm{IC}_{50} \mathrm{RDC}$ values which were the lowest of any of the test compounds (Table 1). Although compound 7 had the lowest MIC $(2.8 \pm 0)$ of any of the test compounds, the $24-\mathrm{h} \mathrm{IC}_{50}$ of $14.8 \pm 0.6 \mathrm{mg} / \mathrm{L}$ was higher than that of isomahanine and subsequently the 24-h $\mathrm{IC}_{50}$ RDC values for 7 were almost a magnitude of order higher than those obtained for isomahanine. Mahanine, an isomer of isomahanine which differed only in the position of an aromatic $\mathrm{CH}_{3}$ moiety, had moderate toxicity against $F$. columnare based on 24-h $\mathrm{IC}_{50}$ results of $10.6 \pm$ $1.6 \mathrm{mg} / \mathrm{L}$. Mahanine and isomahanine were isolated from the leaves of $M$. koenigii (Rutaceae) an edible plant that had been used by people in Southeast Asia for flavoring food [28]. M. koenigii is known to be a rich source of carbazole alkaloids with various biological activities such as anti-tumor, anti-diabetic, anti-mutagenic and antiinflammatory activities [28-32]. In the ethyl acetate extract of $M$. koenigii leaves, the abundance ratio of mahanine to isomahanine was about $3: 1$ as determined by HPLC (Figure 1).

Piperine, the major amide constituent in $P$. nigrum, also had moderate toxicity against $F$. columnare based on 24-h IC $_{50}$ results of $12.1 \pm 0.7 \mathrm{mg} / \mathrm{L}$. Mahanine, 5 and 11 had moderate toxicities against $F$. columnare based on
MIC results (Table 1). Compound 10, the ethyl ester analog of 5, was not toxic towards $F$. columnare at any of the test concentrations evaluated in this study. The nicotinamide constituents 7, 5, and $\mathbf{6}$ were isolated from the ethyl acetate extract of $A$. texana (Rutaceae) leaves. In our previous studies, we have shown the presence of algicidal and termiticidal activities of chromene amides and their analogs [9]. Compounds 5 and $\mathbf{7}$ are geometric isomers that differ only at the double bond. Both the cis and trans isomers occur in the ethyl acetate extract of the leaves of $A$. texana. Only 7, the trans isomer, showed moderate activity against $F$. columnare whereas both compounds at the test concentrations lacked activities against $S$. iniae. These two constituents have been isolated from other Amyris species, specifically A. plumieri and A. sylvatica, [19] Burke and Philip, 1985; [20] Burke and Parkins, 1978; [33] Hasbun et al., 1989, [34] Hasbum and Castro, 1988], but is interesting to note that both isomers are present in $A$. texana leaves with the more abundant isomer being the cis isomer at approximately 3:1 ratio.

Isomahanine also had the strongest activity against $S$. iniae, with a $24-\mathrm{h} \mathrm{IC}_{50}$ of $1.3 \pm 0.1 \mathrm{mg} / \mathrm{L}$ and MIC of 3.5 $\pm 0 \mathrm{mg} / \mathrm{L}$, respectively (Table 2). The RDC values for isomahanine were the lowest of any of the compounds tested in this study. Based on 24-h $\mathrm{IC}_{50}$ and MIC results, mahanine, piperine, $\mathbf{3}$, and $\mathbf{1 3}$ had moderate toxicities against $S$. iniae LA94-426. The $24-\mathrm{IC}_{50}$ of mahanine, piperine, 3, and 13 were $10.2 \pm 8.9,10.0 \pm 0.3,7.7 \pm 1.2$, and $9.1 \pm 0.2$, respectively, while the MIC results were

Table 1. Results of the bioassay evaluation of antimicrobial compounds for toxicity against Flavobacterium columnare (ALM-00173). Numbers in parentheses are the standard error of the mean.

\begin{tabular}{|c|c|c|c|c|c|c|}
\hline \multirow[b]{2}{*}{ Test compound } & \multirow[b]{2}{*}{ 24-h IC ${ }_{50}^{a}$} & \multirow[b]{2}{*}{ MIC $^{\mathbf{b}}$} & \multicolumn{2}{|c|}{$24-h$ IC $_{50}{ }^{a}$} & \multicolumn{2}{|c|}{ MIC $^{\mathrm{b}}$} \\
\hline & & & RDCF $^{\mathrm{c}}$ & RDCO $^{d}$ & RDCF $^{\mathrm{c}}$ & RDCO $^{d}$ \\
\hline Oxytetracycline $\mathrm{HCl}$ & $0.1(0.01)$ & $0.05(0)$ & & & & \\
\hline Florfenicol & $0.17(0.01)$ & $0.36(0)$ & & & & \\
\hline Isomahanine (1) & $1.9(0.2)$ & $3.5(0)$ & $2.8(0.3)$ & $2.7(0.3)$ & $10.0(0)$ & $10.8(0)$ \\
\hline Mahanine (2) & $10.6(1.6)$ & $19.1(15.6)$ & $15.8(2.3)$ & $15.0(2.2)$ & $55.0(45.0)$ & $59.1(48.4)$ \\
\hline Piperine (3) & $12.1(0.7)$ & $28.5(0)$ & $22.0(1.3)$ & $20.9(1.2)$ & $100.0(0)$ & $107.5(0)$ \\
\hline Pellitorine (4) & 46.9 (8.9) & $122.8(100.5)$ & $108.8(20.7)$ & 103.5 (19.7) & $550.0(450.0)$ & $591.4(483)$ \\
\hline (5) & $49.8(1.5)$ & $15.6(12.8)$ & $90.7(2.6)$ & $86.2(2.5)$ & $55.0(45.0)$ & $59.1(48.4)$ \\
\hline (6) & $26.8(2.1)$ & $41.1(0)$ & 33.7 (2.6) & $32.0(2.5)$ & $100.0(0)$ & $107.5(0)$ \\
\hline (7) & $14.8(0.6)$ & $2.8(0)$ & $27.0(1.0)$ & $25.6(1.0)$ & $10.0(0)$ & $10.8(0)$ \\
\hline (10) & $>276.3$ & $>276.3$ & $>518.1$ & $>429.6$ & $>1000.0$ & $>1075.3$ \\
\hline (11) & $56.3(2.4)$ & $12.9(10.6)$ & $124.4(5.2)$ & $118.2(4.9)$ & $55.0(45.0)$ & $59.1(48.4)$ \\
\hline (8) & $120.0(10.9)$ & $218.2(0)$ & $285.0(25.9)$ & $270.9(24.6)$ & $1000.0(0)$ & $1075.3(0)$ \\
\hline (9) & 25.7 (1.5) & $27.1(0)$ & $49.0(2.9)$ & $46.6(2.7)$ & $100.0(0)$ & $107.5(0)$ \\
\hline (13) & $222.7(27.9)$ & $278.3(0)$ & $414.5(51.8)$ & 1621.7 (1178.3) & $1000.0(0)$ & $1075.4(0)$ \\
\hline
\end{tabular}

${ }^{\mathrm{a}} 24-\mathrm{h} \mathrm{IC}_{50}=50 \%$ inhibition concentration in mg/L; ${ }^{\mathrm{b}} \mathrm{MIC}=$ Minimum inhibition concentration in mg/L; ${ }^{\mathrm{c}} \mathrm{RDCF}=\mathrm{Relative-to-drug-control} \mathrm{florfenicol} \mathrm{(} \mu \mathrm{M}$ ); numbers below " 1 " indicate greater activity compared to drug control; ${ }^{\mathrm{d}} \mathrm{RDCO}=$ Relative-to-drug-control oxytetracycline ( $\left.\mu \mathrm{M}\right)$; numbers below " 1 ” indicate greater activity compared to drug control. 


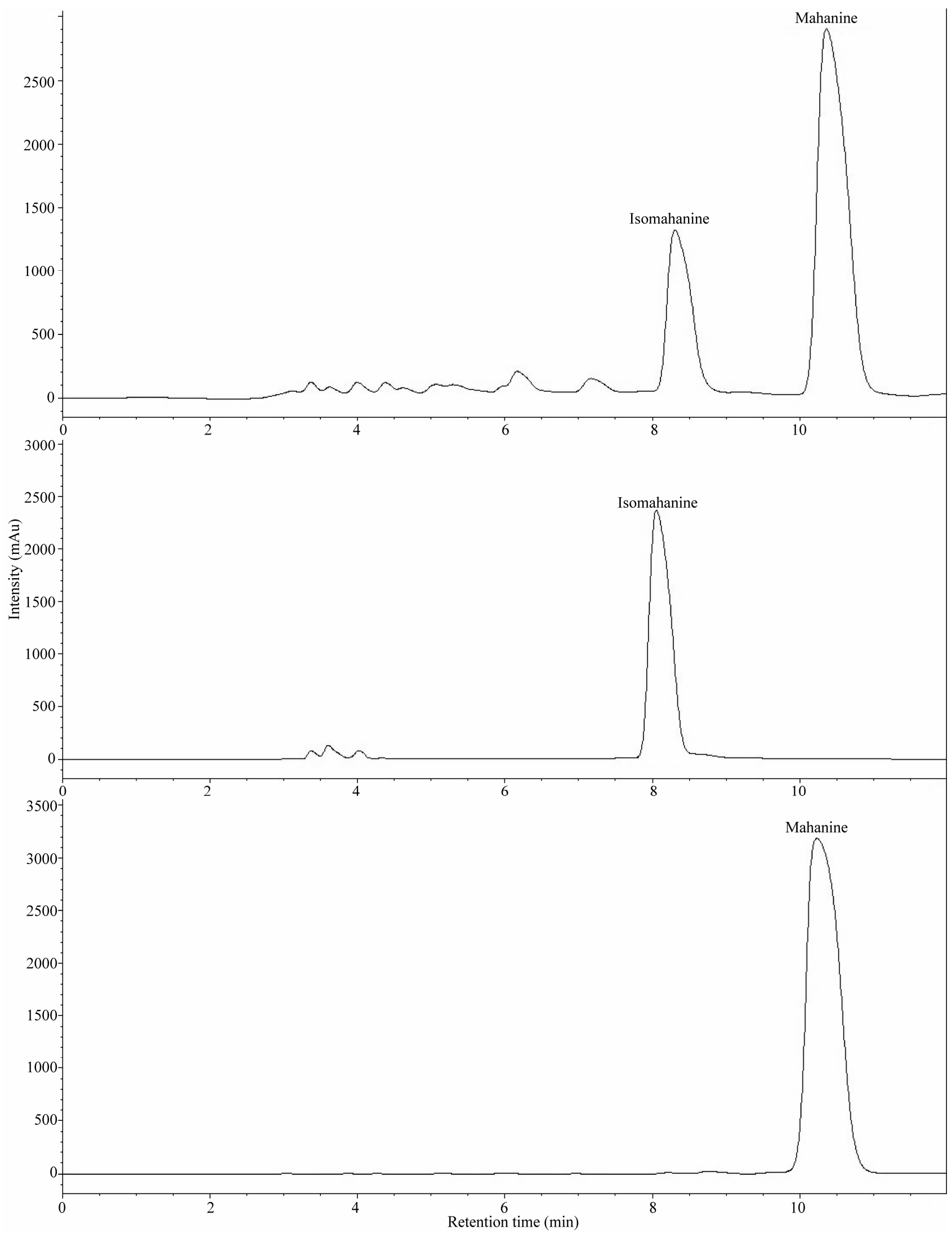

Figure 1. HPLC chromatograms of ethyl acetate extract of leaves of Murraya koenegii. The identified peaks are labeled according to their chemical name. An isocratic solvent system (5\% ethyl acetate in $\mathrm{CH}_{2} \mathrm{Cl}_{2}$ ) was used for the analysis. 
Table 2. Results of the bioassay evaluation of antimicrobial compounds for toxicity against Streptococcus iniae (LA94-426). Numbers in parentheses are the standard error of the mean.

\begin{tabular}{|c|c|c|c|c|c|c|}
\hline \multirow[b]{2}{*}{ Test compound } & \multirow[b]{2}{*}{ 24-h IC $_{50}{ }^{\mathrm{a}}$} & \multirow[b]{2}{*}{ MIC $^{\mathbf{b}}$} & \multicolumn{2}{|c|}{ 24-h IC ${ }_{50}^{\mathrm{a}}$} & \multicolumn{2}{|c|}{ MIC $^{b}$} \\
\hline & & & RDCF $^{c}$ & RDCO $^{d}$ & RDCF $^{\mathrm{c}}$ & $\mathrm{RDCO}^{\mathrm{d}}$ \\
\hline Oxytetracycline $\mathrm{HCl}$ & $0.1(0.01)$ & $0.05(0)$ & & & & \\
\hline Florfenicol & $0.17(0.01)$ & $0.36(0)$ & & & & \\
\hline Isomahanine (1) & $1.3(0.1)$ & $3.5(0)$ & $1.2(0.1)$ & $14.2(0.6)$ & $1.0(0)$ & $111.1(0)$ \\
\hline Mahanine (2) & $10.2(8.9)$ & $19.1(15.6)$ & $9.7(8.3)$ & 116.3 (99.7) & $5.5(4.5)$ & $611.1(500.0)$ \\
\hline Piperine (3) & $10.0(0.3)$ & $28.5(0)$ & $11.7(0.3)$ & $140.0(4.0)$ & $10.0(0)$ & $1111.1(0)$ \\
\hline Pellitorine (4) & $7.7(1.2)$ & $22.3(0)$ & $11.5(1.8)$ & $138.0(22.0)$ & $10.0(0)$ & $1111.1(0)$ \\
\hline (5) & $103.8(10.0)$ & $284.3(0)$ & $121.7(11.7)$ & $1460.0(140.0)$ & $100.0(0)$ & $11,111(0)$ \\
\hline (6) & $>411.0$ & $>411.0$ & $>333.3$ & $>4000.0$ & $>100.0$ & $>11,111.1$ \\
\hline (7) & $>284.3$ & $>284.3$ & $>333.3$ & $>4000.0$ & $>100.0$ & $>11,111.1$ \\
\hline (10) & $>276.3$ & $>276.3$ & $>333.3$ & $>4000.0$ & $>100.0$ & $>11,111.1$ \\
\hline (11) & $61.0(2.4)$ & $234.3(0)$ & 86.7 (3.3) & $1040.0(40.0)$ & $100.0(0)$ & $11,111(0)$ \\
\hline (8) & $131.0(17.5)$ & $218.2(0)$ & $200.0(26.7)$ & $2400.0(320.0)$ & $100.0(0)$ & $11,111(0)$ \\
\hline (9) & $40.7(32.6)$ & $271.3(0)$ & $50.0(40.0)$ & $600.0(480.0)$ & $100.0(0)$ & $11,111(0)$ \\
\hline (13) & $9.1(0.2)$ & $27.8(0)$ & $10.8(0.2)$ & $130.0(2.0)$ & $10.0(0)$ & $1111.1(0)$ \\
\hline
\end{tabular}

${ }^{\mathrm{a}} 24$-h IC ${ }_{50}=50 \%$ inhibition concentration in mg/L; ${ }^{\mathrm{b}} \mathrm{MIC}=$ Minimum inhibition concentration in mg/L; ${ }^{\mathrm{C}} \mathrm{RDCF}=\mathrm{Relative-to-drug-control} \mathrm{florfenicol} \mathrm{(} \mu \mathrm{M}$ ); numbers below " 1 " indicate greater activity compared to drug control; ${ }^{\mathrm{d}} \mathrm{RDCO}=$ Relative-to-drug-control oxytetracycline ( $\left.\mu \mathrm{M}\right)$; numbers below " 1 " indicate greater activity compared.

$19.1 \pm 15.6,28.5 \pm 0,22.3 \pm 0$, and $27.8 \pm 0$, respectively. Compounds 6, 7, and $\mathbf{1 0}$ were not toxic towards $S$. iniae at any of the test concentrations evaluated.

In our previous studies of Rutaceae species, the presence of bioactive constituents and their analogs against some agriculturally important fungi and cyanobacterial pests have been demonstrated [8-10,35]. For example, rutacridone epoxide present in the ethyl acetate extract from roots of Ruta graveolens L. (Rutaceae) was found to be selectively algicidal towards the Gram-negative cyanobacterium Planktothrix (Oscillatoria) perornata [8]. In another study utilizing bioassay-guided fractionation, citbrasine present in the ethyl acetate extract from roots of Swinglea glutinosa (Blanco) Merr. (Rutaceae) was determined to possess moderate toxicity against $P$. perornata [35]. These studies as well as the previously mentioned study of by Meepagala et al. [9] highlight the potential sources of antibacterial compounds that may be present in other members of Rutaceae.

Previous studies have reported on the antimicrobial activities of extracts obtained from various parts of $M$. koenigii [36,37]. In our study, we determined the active compounds in extracts from leaves of $M$. koenigii via bioassay-guided fractionation in the first step of the discovery of potential antibacterial compounds for use against $F$. columnare and $S$. iniae. This is the first study to report on the antibacterial activities of isomahanine against isolates of $F$. columnare and $S$. iniae. The incurporation of isomahanine in fish feed may be one potential delivery method of the antibacterial compound to diseased fish. Additional studies such as palatability studies of feed containing isomahanine would need to be performed prior to any efficacy (e.g., challenge) studies to determine the potential benefits in managing columnaris disease and streptococcosis.

\section{ACKNOWLEDGEMENTS}

The authors would like to thank Jason Martin, Dewayne Harries and Phaedra Page for technical assistance.

\section{REFERENCES}

[1] Plumb, J.A. and Hanson, L.A. (2011) Health maintenance and principal microbial diseases of cultured fishes. 3rd Edition, Wiley-Blackwell, Ames.

[2] Schrader, K.K. and Harries, M.D. (2006) A rapid bioassay for bactericides against the catfish pathogens Edwardsiella ictaluri and Flavobacterium columnare. Aquaculture Research, 37, 928-937.

http://dx.doi.org/10.1111/j.1365-2109.2006.01514.x

[3] Shoemaker, C.A., Olivares-Fuster, O., Arias, C.R. and Klesius, P.H. (2008) Flavobacterium columnare genomovar influences mortality in channel catfish (Ictalurus punctatus). Veterinary Microbiology, 127, 353-359. http://dx.doi.org/10.1016/j.vetmic.2007.09.003

[4] Gaunt, P.S., Gao, D., Sun, F. and Endris, R.G. (2010) Efficacy of florfenicol for control of mortality caused by Flavobacterium columnare infection in channel catfish. Journal of Aquatic Animal Health, 22, 115-122. http://dx.doi.org/10.1577/H09-057.1 
[5] Shoemaker, C.A., Klesius, P.H. and Evans, J.J. (2001) Prevalence of Streptococcus iniae in tilapia, hybrid striped bass, and channel catfish on commercial fish farms in the United States. American Journal of Veterinary Research, 62, 174-177. http://dx.doi.org/10.2460/ajvr.2001.62.174

[6] Klesius, P., Evans, J. and Shoemaker, C.A (2006) US perspective on advancements in fish vaccine development. Aquaculture Health International, 4, 20-21.

[7] Boyd, C.E. and Tucker, C.S. (1998) Pond aquaculture water quality management. Kluwer Academic Publishers, Boston.

[8] Meepagala, K.M., Schrader, K.K., Wedge, D.E. and Duke, S.O. (2005) Algicidal and antifungal compounds from the roots of Ruta graveolens and synthesis of their analogs. Phytochemistry (Elsevier), 66, 2689-2695. http://dx.doi.org/10.1016/j.phytochem.2005.09.019

[9] Meepagala, K.M., Schrader, K.K., Burandt, C.L., Wedge, D.E. and Duke, S.O. (2010) New class of algicidal compounds and fungicidal activities derived from a chromene amide of Amyris texana. Journal of Agricultural and Food Chemistry, 58, 9476-9482. http://dx.doi.org/10.1021/jf101626g

[10] Oliva, A., Meepagala, K.M., Wedge, D.E., Harries, D., Hale, A.L., Aliotta, G. and Duke, S.O. (2003) Natural fungicides from Ruta graveolens L. leaves, including a new quinolone alkaloid. Journal of Agricultural and Food Chemistry, 51, 890-896. http://dx.doi.org/10.1021/jf0259361

[11] De Feo, V., De Simone, F. and Senatore, F. (2002) Potential allelochemicals from the essential oil of Ruta graveolens. Phytochemistry, 61, 573-578. http://dx.doi.org/10.1016/S0031-9422(02)00284-4

[12] Sallal, A.J. and Alkofahi, A. (1996) Inhibition of the hemolytic activities of snake scorpion venoms in vitro with plant extracts. Biomedical Letters, 53, 211-215.

[13] Aliotta, G., Cafiero, G., De Feo, V. and Sacchi, R. (1994) Potential allelochemicals from Ruta graveolens L. and their action on radish seeds. Journal of Chemical Ecology, 20, 2761-2775. http://dx.doi.org/10.1007/BF02098388

[14] Aliotta, G., Cafiero, G., De Feo, V., Di Blasio, B., Iacovino, R. and Oliva, A. (2000) Allelochemicals from rue (Ruta graveolens L.) and olive (Olea europaea L.) oil mill waste waters as potential natural pesticides. Current Topics in Phytochemistry, 3, 167-177.

[15] Decostere, A., Henckaerts, K. and Haesebrouck, F. (2002) An alternative model to study the association of rainbow trout (Oncorhynchus mykiss L.) pathogens with the gill tissue. Laboratory Animals, 36, 396-402. http://dx.doi.org/10.1258/002367702320389053

[16] Reisch, J., Goj, O., Wickramasinghe, A., Herath, H.M.T. and Henkel, G. (1992) Natural products chemistry. Part 148. Carbazole alkaloids from seeds of Murraya koenigii. Phytochemistry, 31, 2877-2879. http://dx.doi.org/10.1016/0031-9422(92)83651-E

[17] Atta-ur-Rahman, Z.R. and Firdous, S. (1988) NMR studies on mahanine. Fitoterapia, 59, 494-495.

[18] De Araujo-Junior, J.X., Da-Cunha, E.V.L., Chaves, M.C. de O. and Gray, A.I. (1997) Piperdardine, a piperidine al- kaloid from Piper tuberculatum. Phytochemistry, 44, 559561. http://dx.doi.org/10.1016/S0031-9422(96)00503-1

[19] Burke, B.A. and Philip, S. (1985) Amyris of Jamaica. A new nicotinamide from Amyris plumieri D.C. (Rutaceae). Heterocycles, 23, 257-260. http://dx.doi.org/10.3987/R-1985-02-0257

[20] Burke, B.A. and Parkins, H. (1978) Amyris of Jamaica. Nicotinamides of Amyris plumieri D.C., (Rutaceae). Tetrahedron Letters, 19, 2723-2726. http://dx.doi.org/10.1016/S0040-4039(01)91587-4

[21] Dreyer, D.L. (1970) Citrus bitter principles-X: Extractives of Swinglea glutinosa (bl.) merr. Tetrahedron, 26, 5745-5751. http://dx.doi.org/10.1016/0040-4020(70)80011-4

[22] Dreyer, D.L., Rigod, J.F., Basa, S.C., Mahanty, P. and Das, D.P. (1980) Chemotaxonomy of the rutaceae-XII1: The occurrence of severine in Atalantia monophylla and Hesperethusa crenulata. A revised structure for severine. Tetrahedron, 36, 827-829. http://dx.doi.org/10.1016/S0040-4020(01)93701-9

[23] Saito, Y., Ouchi, H. and Takahata, H. (2008) Carboxamidation of carboxylic acids with 1-tert-butoxy-2-tert-butoxycarbonyl-1,2-dihydroisoquinoline (BBDI) without bases. Tetrahedron, 64, 11129-11135. http://dx.doi.org/10.1016/j.tet.2008.09.094

[24] Motoshima, K., Ishikawa, M., Hashimoto, Y. and Sugita, K. (2011) Peroxisome proliferator-activated receptor agonists with phenethylphenylphthalimide skeleton derived from thalidomide-related liver $\mathrm{X}$ receptor antagonists: Relationship between absolute configuration and subtype selectivity. Bioorganic \& Medicinal Chemistry, 19, 31563172. http://dx.doi.org/10.1016/j.bmc.2011.03.065

[25] Banerji, A., Bandyopadhyay, D., Sarkar, M., Siddhanta, A. K., Pal, S.C., Ghosh, S., Abraham, K. and Shoolery, J.N. (1985) Structural and synthetic studies on the retrofractamides-Amide constituents of Piper retrofractum. Phytochemistry (Elsevier), 24, 279-284. http://dx.doi.org/10.1016/S0031-9422(00)83537-2

[26] Strunz, G.M. and Finlay, H. (1994) Concise, efficient new synthesis of pipercide, an insecticidal unsaturated amide from Piper nigrum, and related compounds. Tetrahedron, 50, 11113-11122. http://dx.doi.org/10.1016/S0040-4020(01)89414-X

[27] Rosario, S.L., Silva, A.J. and Parente, J.P. (1996) Alkamides from Cissampelos glaberrima. Planta Medica, 62, 376-377. http://dx.doi.org/10.1055/s-2006-957913

[28] Fiebig, M., Pezzuto J.M., Soejarto, D.D. and Kinghorn, A.D. (1985) Koenoline, a further cytotoxic carbazole alkaloid from Murraya koenigii. Phytochemistry (Elsevier), 24, 3041-3043. http://dx.doi.org/10.1016/0031-9422(85)80052-2

[29] Nagappan, T., Ramasamy, P., Abdul Wahid, M.E., Segaran, T.C. and Vairappan, C.S. (2011) Biological activity of carbazole alkaloids and essential oil of Murraya koenigii against antibiotic resistant microbes and cancer cell lines. Molecules, 16, 9651-9664. http://dx.doi.org/10.3390/molecules16119651

[30] Argal, M.S., Kumar, S., Choudhary, H.S., Thakkar, R.M., 
Verma, S.K. and Seniya, C. (2011) The efficacy of Murraya koenigii leaf extract on some bacterial and a fungal strain by disc diffusion method. Journal of Chemical and Pharmaceutical Research, 3, 697-704.

[31] Vasudevan, M. and Parle, M. (2009)Antiamnesic potential of Murraya koenigii leaves. Phytotherapy Research, 23, 308-316. http://dx.doi.org/10.1002/ptr.2620

[32] Ramsewak, R.S., Nair, M.G., Strasburg, G.M., DeWitt, D.L. and Nitiss, J.L. (1999) Biologically active carbazole alkaloids from Murraya koenigii. Journal of Agricultural and Food, 47, 444-447. http://dx.doi.org/10.1021/jf9805808

[33] Hasbun, C., Castro, O. and Andrade, R. (1989) Two new chromenilated dihydrostyrilamides from Amyris sylvatica. Journal of Natural Products, 52, 868-870. http://dx.doi.org/10.1021/np50064a036
[34] Hasbun, C. and Castro, O. (1988) Occurrence of coumarins and amides in the bark of three Amyris series from Costa Rica. Spectroscopy, 6, 181-184.

[35] Purcaro, R., Schrader, K.K., Burandt, C., Della Greca, M. and Meepagala, K.M. (2009) Algicide constituents from Swinglea glutinosa. Journal of Agricultural and Food Chemistry, 57, 10632-10635. http://dx.doi.org/10.1021/jf902561c

[36] Nutan, M.T.H., Hasnat, A. and Rashid, M.A. (1998) Antibacterial and cytotoxic activities of Murraya koenigii. Fitoterpia, 69, 173-175.

[37] Vats, M., Singh, H. and Sardana, S. (2011) Phytochemical screening and antimicrobial activity of roots of Murraya koenigii (Linn.) Spreng. (Rutaceae). Brazilian Journal of Microbiology, 42, 1569-1573. http://dx.doi.org/10.1590/S1517-83822011000400044 


\section{SUPPLEMENT}
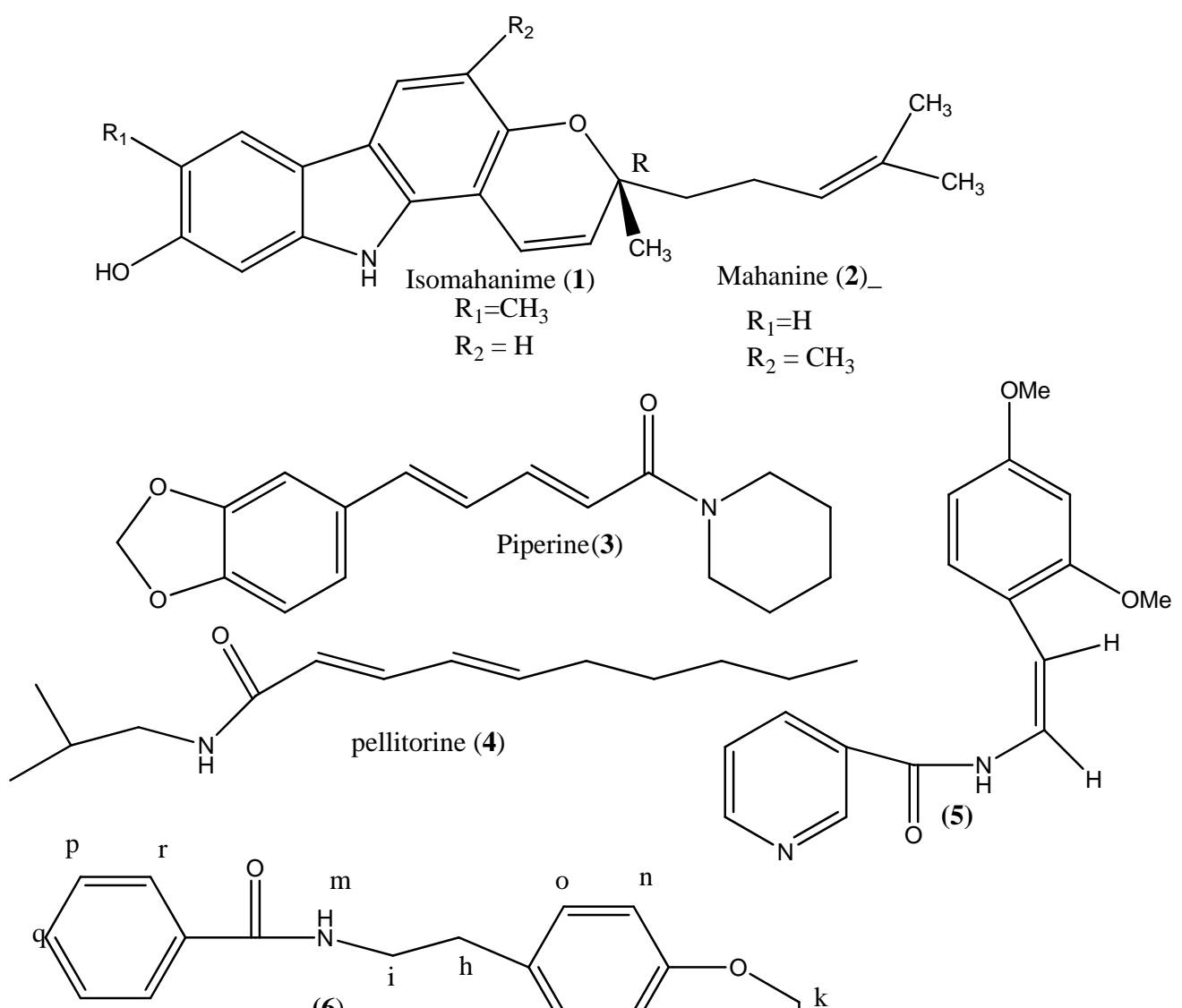

(6)
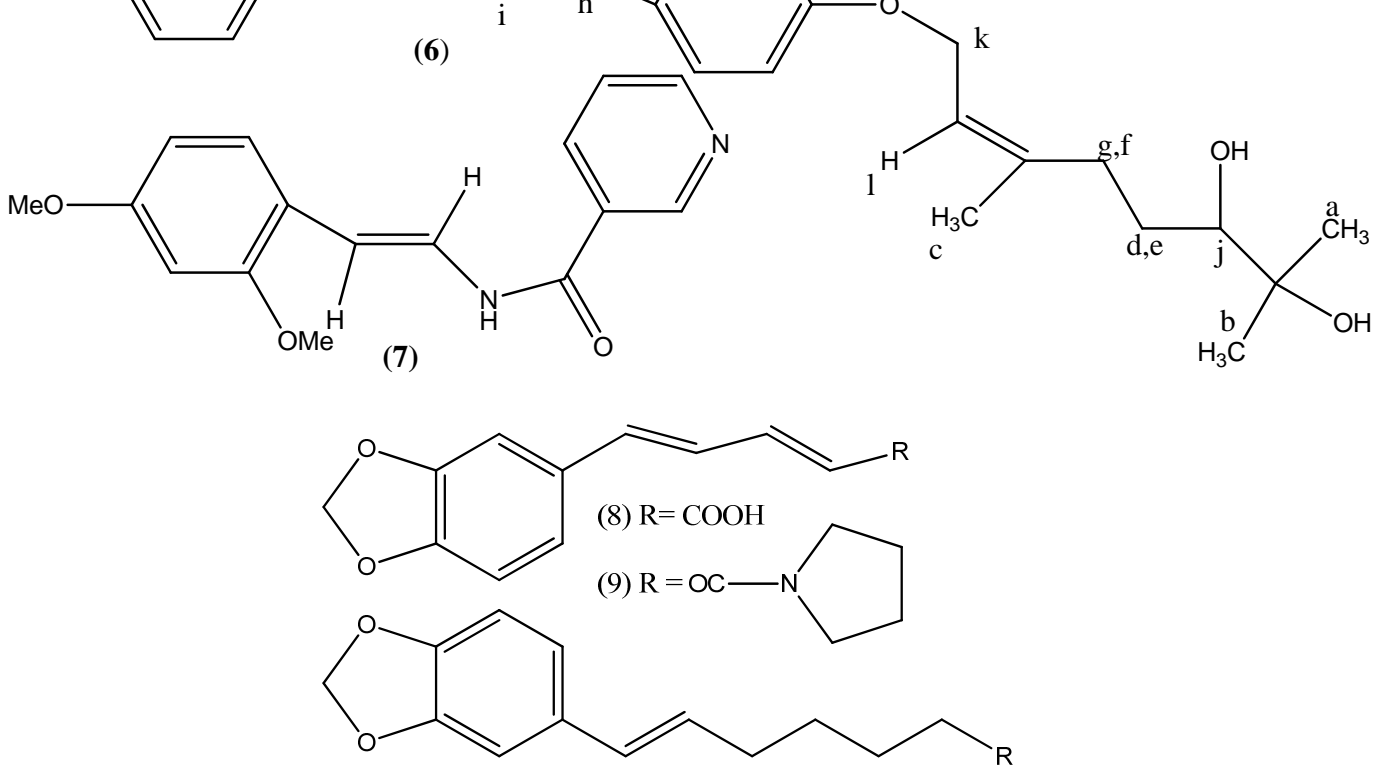

(10) $\mathrm{R}=\mathrm{COOEt}$

(11) $\mathrm{R}=\mathrm{CH}_{2} \mathrm{OH}$

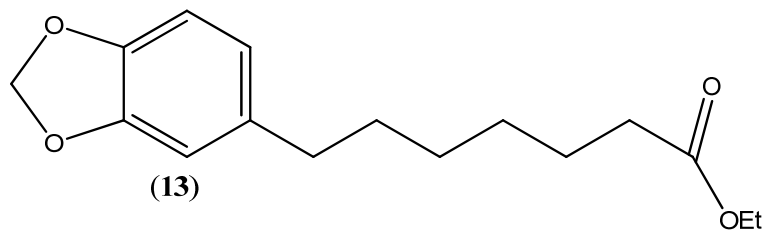




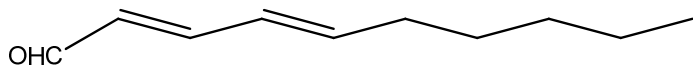

(2E,4E)-deca-2,4-dienal

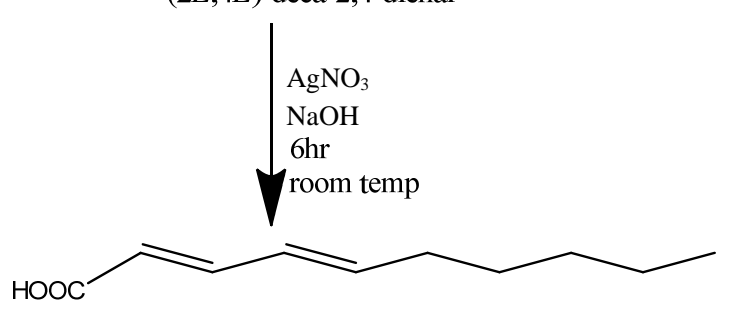

(2E,4E)-deca-2,4-dienoic acid (12)

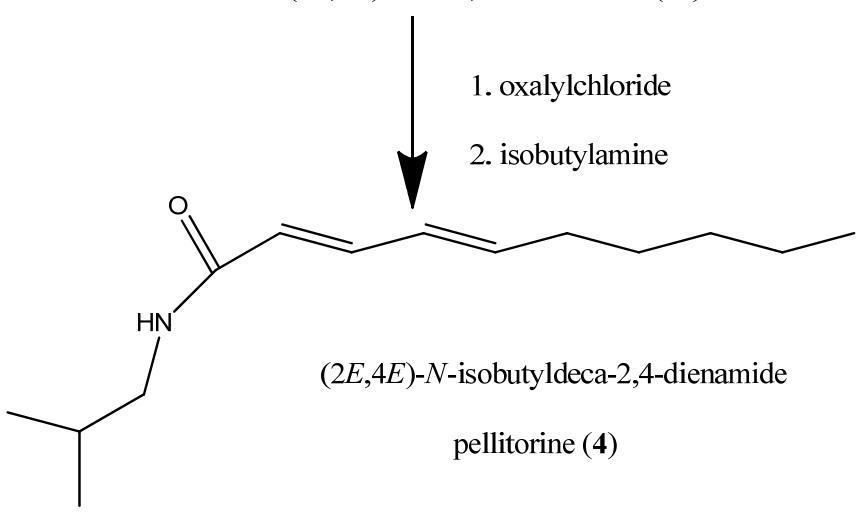

Synthesis of pellitorine 